\title{
Exploring air pollution and its solutions in developing countries
}

\author{
Vu Anh Tuyet, Dang Thanh Xua, Nguyen Thanh Nhu Y, Nguyen Dang Linh Chi, \\ Nguyen Thi Hanh, Nguyen Duc Huy, Nguyen Mai Linh, Phung Duc Manh, \\ Nguyen Truc Thao My
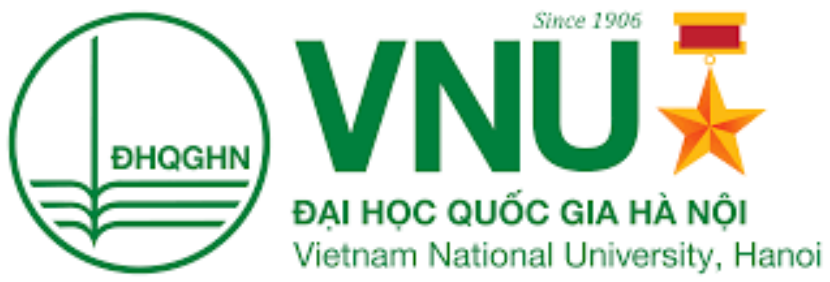

\author{
Faculty of Law, Vietnam National University \\ Xuan Thuy, Cau Giay, Hanoi
}

January 17, 2022

Preprint DOI: https://osf.io/4vzf2

In the era of industrialization, one of the most worrying issues is pollution, notably air pollution which occurs not only in Vietnam, a developing country, but also many nations around the world. According to the World Health Organization (WHO), air pollution results in deaths of nearly 7 million (Jillian Mackenzie \& Jeff Turrentine, 2016) people per year. The proportions of more than $95 \%$ (Ý, 2020) of the world's population facing air pollution and over $60 \%$ (Ý, 2020) of people living in bad conditions which do not meet WHO's basic standards were reported by the Health Effects Institute (HEI). Certain data have shown that Vietnam is ranked in the top 10 (Ý, 2020) most polluted countries in Asia (Nguyen et al., 2021; Van Khuc et al., 2020; Q. Vuong et al., 2021).

When it comes to the origin of the air pollution, there are two major contributing factors: artificial and natural causes. In particular, while volcanoes, wildfires, dust storms, flora and fauna decomposition lead to natural causes, " Artificial causes are mainly due to the burning fuel of industries which adds sulfur dioxide to the air, traffic overload and human activities" (Pandey, 
2016). It is because of all the factors mentioned previously that seriously pose threat to the atmosphere, do harm to not only human's well-being but also the environment we are living in, specifically dust, ozone layer depletion, acid rain, etc. Therefore, in order to protect the air as well as not to slow down industrialization and modernization, cutting-edge technology needs to be applied, toxic gas and fuels need to be limited. In addition, it is necessary to develop, invest in methods to purify the air and plant more trees.

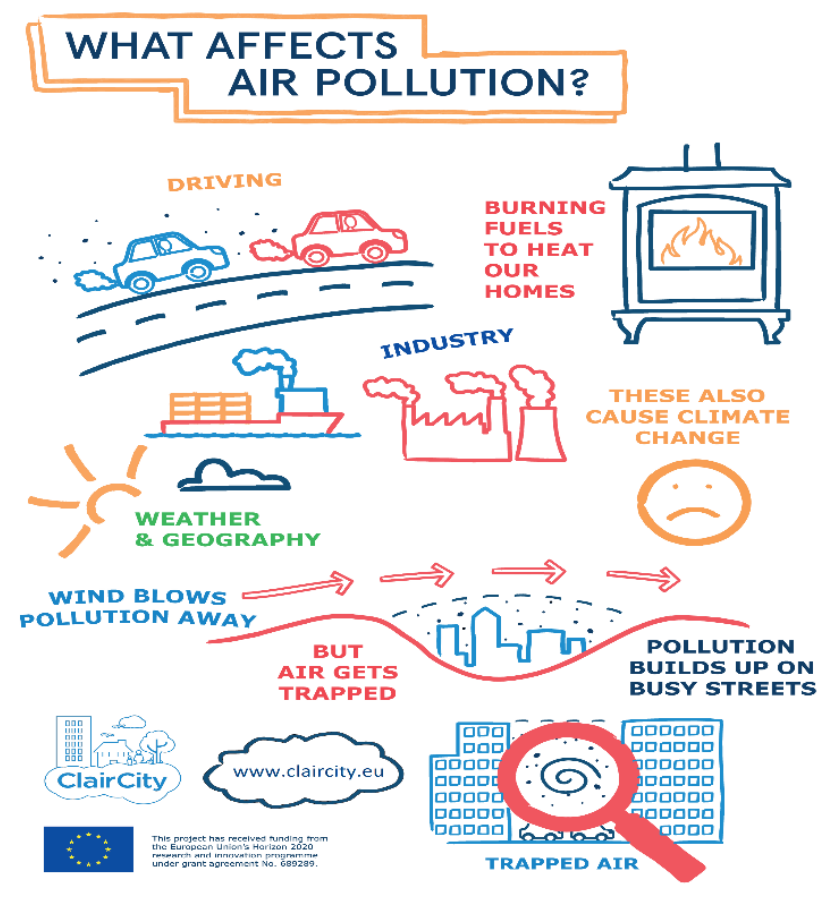

Figure 1. Causes of air pollution. Source Internet 


\section{THE IMPACTS OF WORSENING AIR POLLUTION ARE MANY....}
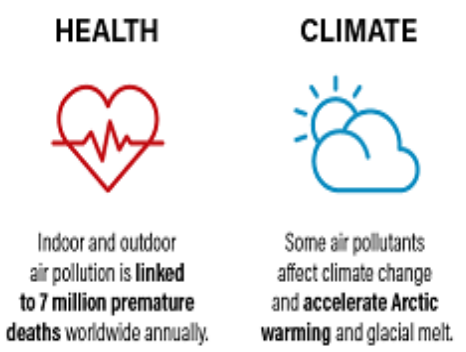

WATER

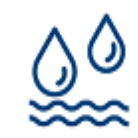

Air pollution affects rainfall patterns, storm intensities

and regional weather patterns such as the monscon.

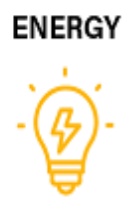

Haze and dust from air pollution can reduce solar yields by as much as $25 \%$
FOOD

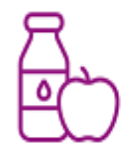

Air pollution

reduces global crop yields -- up to $15 \%$ for wheat and soy and 5\%for maize.

wri.org/air-pollution

Figure 2. Air pollution's impacts. Source: wri.org/air-pollution

In recent years, humans have made certain efforts to improve and prevent the growinglyprevalent- air-pollution. However, we still struggle with diverse difficulties and challenges, typically the remaining problems in the COP26-climate conference. First to be talked about is the "Paris Agreement", which concerns the parties by mentioning the establishing a carbon emission market and allowing nations to exchange carbon credits. Along with language and substance barriers between nations as the Article 6 contains too much technical information, countries' taking advantage of gaps make estimating the amount of greenhouse gas being cut or marketed impossible. Secondly is the problem of "No liability fund". This frustrates developing countries since they need funds to compensate for damages caused by the climate catastrophe. The Glasgow Climate Compact does not call for funding but negotiating although they are aware of losses and damages of nations. In conclusion, this fund can take years to be established provided the parties intend to do so. (T. D. T, 2021)

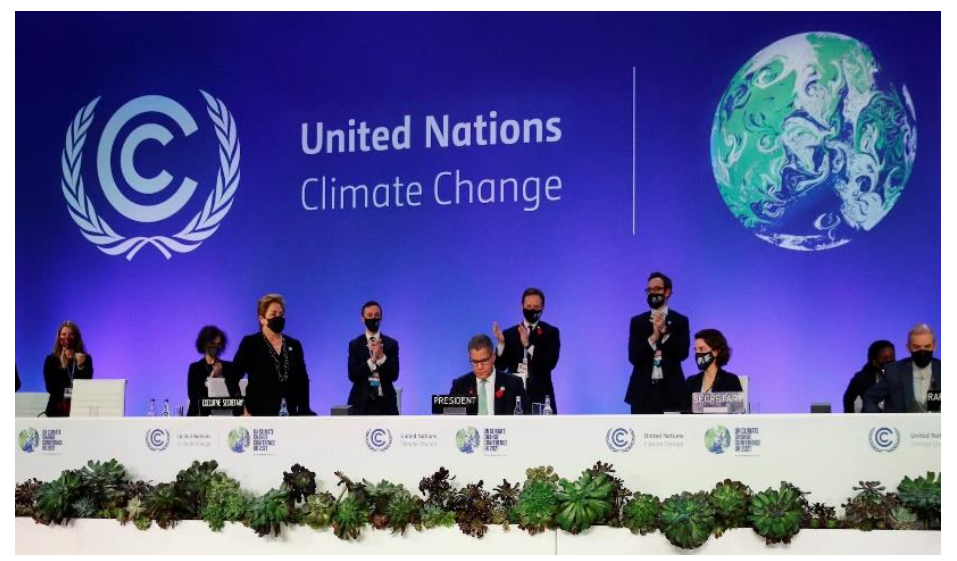

Figure 3. COP26-climate. Source (UNEP, 2021)

Air pollution has been a global dilemma andit is not only an environmental issue but also a human rights issue. According to David R. Boyd, Special Rapporteur on human rights and the environment for the United Nations: "The number of 7 million people who die each year due to 
air pollution is more than the total number of deaths. war deaths, murder, tuberculosis, HIV, AIDS and malaria combined" (S. Larson, 2019). Moreover, the United Nations' latest statistics on the environment said that: "If you live in a city in a low or middle-income country, the chances of breathing clean air are very low - $97 \%$ of cities in these countries do not meet air quality guidelines" (U. N. E. Programme, 2019).

All the information and statistics above show that air pollution greatly affects the health of people, especially children, whose benefit needs to be prioritized. People who are destroying the environment also means that their basic rights are being violated by themselves. For decades, governments have considered air pollution as an environmental problem, it has recently begun to be considered as a health problem. Air pollution at the present's scale clearly violates the rights to life and health, the rights of children and the right to live in a safe, clean, healthy and sustainable environment (D. R. Boyd, 2019). According to Principle 1 of the Stockholm Declaration (1972) of the World Health Organization WHO, which aims to establish the foundation for linking human rights, health, and environmental protection, states that: "Man has the fundamental right to freedom, equality and adequate conditions of life, in an environment of a quality that permits a life of dignity and well-being, and he bears a solemn responsibility to protect and improve the environment for present and future generations" (Shelton, 2002). Environmental conditions clearly help to determine the extent to which people enjoy basic rights to life, health, food and housing, livelihoods and traditional culture.

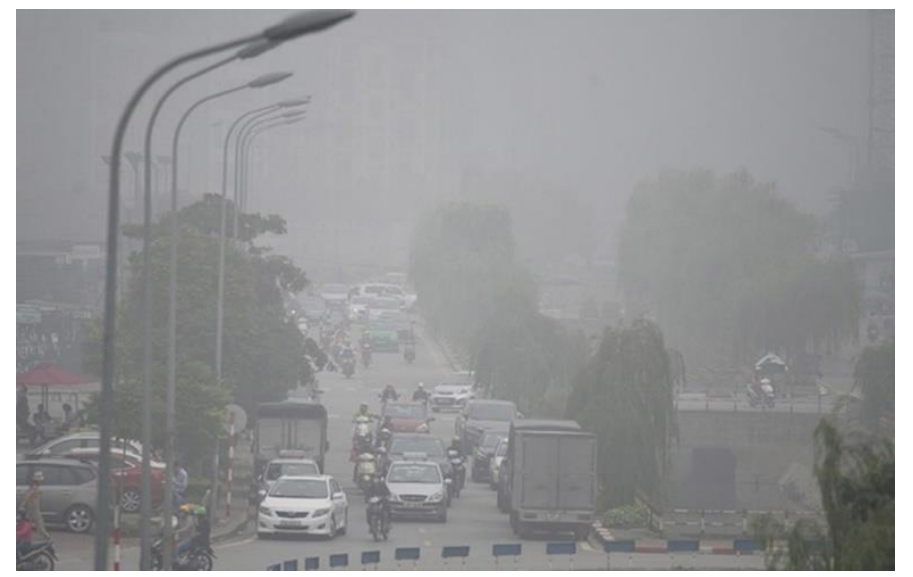

Figure 4. Air pollution in Hanoi, Vietnam. Source:(VNA, 2019)

Facing the situation of serious air pollution, the Government of each country has different solutions. According to the Clean Air Fund, in the United States, after the enactment of the Clean Air Act in 1970, the emissions of six common pollutants in this country were monitored under the Clean Air Act and averaged reduction. 69 percent while GDP grew by 238 percent (Baidu.com, 2015). In India, the New Delhi Air Quality Monitoring Board recommends that all educational institutions should be temporarily closed until further notice due to the air pollution becoming severe and difficult to control. (M. Tâm, 2021). In Vietnam, the Ministry of Natural Resources and Environment proposed to issue a series of urgent measures to overcome the problem of air pollution, such as developing and implementing a local air quality management plan. ... (V. Sơn, 
2020) Recently, on November 23, 2021, the Prime Minister issued Decision 1973/QD-TTg 2021 on "National plan on air quality management for the period 2021-2025" (Phủ, 2021).

To tackle the problems, there are many measures and or solutions. Firstly, it is necessary to enact a separate Law on air pollution. Secondly, it is necessary to be strict in regulations and decrees on compliance with the world's unified air indicators, set forth in the economic and life fields. Thirdly, environmental culture would be a key to the problem (Q.-H. Vuong, 2021; Q. H. et al. Vuong, 2018). Environmental culture here refers to perceptions, actions, and contributions from people to improving polluted air. Besides, using the 3D mechnism and culture tower, it is important and critical to undertake the solution ecosystem inlcuding science and technology, communications, collaborations and strong enforcement (Khuc, 2022; Vuong, Q. H., 2022; Q. H. Vuong, 2018, 2021).In the era of digital technology, humans cannot avoid destroying nature. Having been aware of this circumstance, countries around the world have made their own laws and entered into common alliances to prevent environmental destruction and turn it into a repairable problem. By presenting the realities of society, our group has shown everyone the most honest perspective on air pollution and the measures taken by countries on this problem.

\section{References}

Baidu.com. (2015). Image source. Baidu.Com.

D. R. Boyd. (2019). The human right to breathe clean air. National Center for Biotechnology Information. https://www.ncbi.nlm.nih.gov/pmc/articles/PMC6923778/

Jillian Mackenzie \& Jeff Turrentine. (2016). Air pollution everything you need now. Natural Resources Defense Council. https://www.nrdc.org/stories/air-pollution-everything-youneed-know\#sec1

Khuc, Q. Van. (2022). Về khả năng ứng dụng của hệ xử lý thông tin 3D và nguyên lý bán dẫn giá trị trong tìm kiếm giải pháp cho vấn đề ô nhiễm môi trường và biến đổi khí hậu ở Việt Nam. Tạp Chí Kinh Tế và Dư Báo, 1-5. https://kinhtevadubao.vn/ve-kha-nang-ung-dungcua-he-xu-ly-thong-tin-3d-va-nguyen-ly-ban-dan-gia-tri-trong-tim-kiem-giai-phap-cho-vande-o-nhiem-moi-truong-va-bien-doi-khi-hau-o-viet-nam-20840.html

M. Tâm. (2021). Ân Độ : New Delhi đóng cửa trường học do ô nhiễm không khí nghiêm trọng. Việt Nam Plus. https://www.vietnamplus.vn/an-do-new-delhi-dong-cua-truong-hoc-do-onhiem-khong-khi-nghiem-trong/754445.vnp

Nguyen, T. C., Le, H. T., Nguyen, H. D., Le, T. H., \& Nguyen, H. Q. (2021). Estimating economic benefits associated with air quality improvements in Hanoi City: An application of a choice experiment. Economic Analysis and Policy, 71, 420-433. https://doi.org/10.1016/j.eap.2021.06.009

Pandey, A. \& S. P. (2016). A dual-route approach to orthographic processing. Frontiers. http://www.frontiersin.org/language_sciences/10.3389/fpsyg.2011.00054/full

Phủ, T. tướng C. (2021). Quyết định 1973/QĐ-TTg 2021 Kế hoạch quốc gia về quản lý chất lượng môi trường không khí giai đoạn 2021-2025. In Thu Viện Pháp Luật. 
https://huvienphapluat.vn/van-ban/Tai-nguyen-Moi-truong/Quyet-dinh-1973-QD-TTg2021-Ke-hoach-quoc-gia-ve-quan-ly-chat-luong-moi-truong-khong-khi-495464.aspx

S. Larson. (2019). Time to see air pollution as a human right threat: U.N. REUTERS. https://www.reuters.com/article/us-health-pollution-rights-idUSKCN1QL268

Shelton, D. (2002). Human rights, health \& environmental protection : linkages in law \& practice a background paper for the world health organization. Notre Dame LOndon Law Centre, 1, 1-24.

https://www.who.int/hhr/information/Human_Rights_Health_and_Environmental_Protectio n.pdf

T. D. T. (2021). Điểm lại những thành công và thất bại của hội nghị khí hậu COP26. Báo Tin Tíc. https://baotintuc.vn/the-gioi/diem-lai-nhung-thanh-cong-va-that-bai-cua-hoi-nghi-khihau-cop26-20211115170816281.htm

U. N. E. Programme. (2019). Clean air as a human right. UNEP. https://www.unep.org/newsand-stories/story/clean-air-human-right

UNEP. (2021). COP26 ends with agreement but falls short on climate action. UNEP. https://www.unep.org/news-and-stories/story/cop26-ends-agreement-falls-short-climateaction

V. Sơn. (2020). Khắc phục nạn ô nhiễm không khí: Bộ Tài nguyên và Môi trường đề xuất ban hành một loạt biện pháp cấp bách. Báo Pháp Luật. https://baophapluat.vn/khac-phuc-nan-onhiem-khong-khi-bo-tai-nguyen-va-moi-truong-de-xuat-ban-hanh-mot-loat-bien-phap-capbach-post $348554 . h t m l$

Van Khuc, Q., Phu, T. V., \& Luu, P. (2020). Dataset on the Hanoian suburbanites' perception and mitigation strategies towards air pollution. Data in Brief, 33, 106414.

https://doi.org/10.1016/j.dib.2020.106414

VNA. (2019). Hà Nội residents worry about air pollution. Vietnamplus. https://en.vietnamplus.vn/hanoi-residents-worry-about-air-pollution/149105.vnp

Vuong, Q. H., et al. (2022). Covid-19 vaccines production and societal immunization under the serendipity-mindsponge-3D knowledge management theory and conceptual framework. Humanities and Social Sciences Communications, 9; doi:10.1057/s41599-022-01034-6. Available at: https://www.nature.com/articles/s41599-022-01034-6

Vuong, Q.-H. (2021). Western monopoly of climate science is creating an eco-deficit culture. Economy, Land \& Climate Insight, 11, 1-9. https://elc-insight.org/western-monopoly-ofclimat

Vuong, Q. H. (2018). The (ir)rational consideration of the cost of science in transition economies. Nature Human Behaviour, 2(1), 5. https://doi.org/10.1038/s41562-017-0281-4

Vuong, Q. H. (2021). The semiconducting principle of monetary and environmental values exchange. Economics and Business Letters, 10(3), 284-290.

https://doi.org/10.17811/ebl.10.3.2021.284-290

Vuong, Q. H. et al. (2018). Cultural additivity: behavioural insights from the interaction of Confucianism, Buddhism and Taoism in folktales. Palgrave Communications, 4(143). 
https://doi.org/10.1057/s41599-018-0189-2

Vuong, Q., Phu, T. V., Le, T. T., \& Khuc, Q. Van. (2021). Exploring Inner-City Residents' and Foreigners' Commitment. Data, 6(39). https://doi.org/10.17632/8sv4j2r9wk.2

Ý, L. T. (2020). Ô nhiễm không khí: giải pháp toàn cầu và ở Việt Nam trong phát triển bền vững. GREENID. http://greenidvietnam.org.vn/o-nhiem-khong-khi-giai-phap-toan-cau-va-o-vietnam-trong-phat-trien-ben-vung.html 